Kumawula, Vol. 3, No.3, Desember 2020, Hal 375 - 386 DOI: https://doi.org/10.24198/kumawula.v3i3.25583

ISSN 2620-844X (online)

Tersedia online di http://jurnal.unpad.ac.id/kumawula/index

\title{
HYGIENE SANITASI MAKANAN JAJANAN KANTIN SEBUAH PERGURUAN TINGGI SWASTA $X$ DI BANDUNG UNTUK MENINGKATKAN KESEHATAN LINGKUNGAN
}

\author{
Ria Satyarini ${ }^{1}$, Rizka Nugraha Pratikna ${ }^{2}$, Fernando Mulia ${ }^{3}$, Vera Intanie Dewi ${ }^{*}$ \\ 1,2,3,4 Program Studi Manajemen, Universitas Katolik Parahyangan \\ * Korespondensi: vera_id@unpar.ac.id
}

\begin{abstract}
Food hygiene sanitation is an effort to control the factors of food, people, places and equipment that can or may cause illness or health problems (RI Minister of Health Decree number 715). From the BEDO and ILO hygiene training materials, two things are very important and actually easy to be done by food sellers in the canteen, namely personal hygiene management (concerning food and beverage sellers in the canteen) and kitchen management. This paper examines differences in perceptions between food and beverage vendors in the cafeteria of a private tertiary institution in Bandung and what is felt by consumers, as many as 450 students. From the collected data a descriptive analysis is then carried out to see the perception of the condition of sanitation hygiene at that time from two points of view, namely sellers and buyers. Descriptive analysis is done by calculating the average respondent's answers from each statement and then presented in graphical form and narrated with reference to relevant theory studies. From the discussion that has been done, interesting findings were found related to knowledge about personal hygiene management from food vendors and the drinks in the canteen. The results obtained shows that their knowledge is adequate but can still be improved to be better as seen from the condition that the food vendors in the canteen have realized the importance of cleanliness for them. However, the dimensions of kitchen management related to canteen facilities and assistance from the canteen manager i.e. the university still needs to be improved because it is in the low category.
\end{abstract}

Keywords: Canteen; Environment; Hygiene; Health; Sanitation

\begin{abstract}
ABSTRAK
Hygiene sanitasi makanan jajanan adalah upaya untuk mengendalikan faktor makanan, orang, tempat dan perlengkapannya yang dapat atau mungkin dapat menimbulkan penyakit atau gangguan .Dari bahan pelatihan hygiene BEDO dan ILO didapat dua hal yang sangat penting dan sebenarnya mudah untuk dilakukan oleh penjual makanan di kantin yaitu pengelolaan kebersihan pribadi (menyangkut penjual makanan dan minuman di kantin) serta pengelolaan dapur. Penelitian ini dilakukan untuk mengetahui persepsi pembeli (dalam hal ini mahasiswa) tentang hygiene sanitasi di satu kantin di PTS di Bandung. Sampel terdiri dari 450 mahasiswa yang menjadi konsumen pada kantin tersebut.

Analisis deskriptif dilakukan terhadap hasil kuesioner dengan menghitung rata - rata jawaban responden dari setiap pernyataan dan selanjutnya disajikan dalam bentuk grafik dan dinarasikan dengan mengacu pada kajian teori yang relevan. Dari pembahasan yang telah dilakukan, ditemukan temuan yang menarik terkait pengetahuan akan pengelolaan kebersihan pribadi dari para penjual makanan dan minuman yang ada di kantin tersebut. Hasil temuan ini kemudian dikomunikasikan kepada para penjual pada acara pelatihan Hygiene sanitasi. Hasil yang didapat bahwa pengetahuan mereka sudah cukup baik dan masih dapat ditingkatkan menjadi baik dan sangat baik dilihat dari adanya kondisi bahwa penjaja makanan di kantin tersebut sudah menyadari pentingnya arti kebersihan bagi mereka. Akan tetapi dimensi pengelolaan dapur yang berhubungan dengan fasilitas kantin dan bantuan dari pengelola kantin yaitu pihak perguruan tinggi masih harus diperbaiki karena berada pada kategori rendah.
\end{abstract}

Keywords: Kantin; Lingkungan; Hygiene; Kesehatan; Sanitasi 


\section{PENDAHULUAN}

Kesehatan merupakan hal yang sangat penting dan perlu dijaga dengan sebaik mungkin. Salah satu yang menjadi penyebab terganggunya kesehatan seseorang adalah bersumber dari makanan. Asupan makanan sehat dan bergizi menjadi perhatian utama. Namun, selain memperhatikan asupan makanan sehat dan bergizi ada hal penting yang juga perlu diperhatikan agar tubuh tetap sehat dan kesehatan lingkungan yang baik dapat terjaga. Hygiene sanitasi makanan jajanan adalah salah satunya. Hygiene sanitasi makanan jajanan merupakan upaya pencegahan yang menitikberatkan pada kegiatan yang perlu dilakukan untuk membebaskan makanan dan minuman dari segala bahaya yang dapat mengganggu kesehatan, mulai dari sebelum makanan diproduksi, selama dalam proses pengolahan, penyimpanan, pengangkutan sampai pada saat dimana makanan dan minuman tersebut siap untuk dikonsumsikan kepada masyarakat atau konsumen ((Prabu, 2008; Sumarni et al., 2020).

Pemahaman lain mengenai Hygiene sanitasi adalah upaya untuk mengendalikan faktor makanan, orang, tempat dan perlengkapannya yang dapat atau mungkin dapat menimbulkan penyakit atau gangguan kesehatan (Persyaratan Hygiene Sanitasi Jasaboga Menteri Kesehatan Republik Indonesia, 2003). Pengelolaan hygiene sanitasi menjadi penting karena berhubungan dengan bagaimana makanan, orang, tempat atau perlengkapan yang ada dapat dengan mudahnya menimbulkan penyakit dan berbahaya bagi umum. Hygiene sanitasi sangat penting dipahami oleh para penjaja atau penjual makanan yang menjajakan makanannya di masyarakat. Penyedia makanan ini banyak sekali ditemui pada fasilitas-fasilitas lingkungan umum seperti pusat perbelanjaan, perkantoran, sekolah dan perguruan tinggi, juga tempat hiburan. Salah satu fasilitas umum yang memiliki area penjaja penyedia makanan adalah perguruan tinggi atau perguruan tinggi, biasanya disebut kantin. Kantin melayani kebutuhan makan bagi mahasiswa maupun karyawan yang bekerja di perguruan tinggi tersebut. Sayangnya seringkali pengelolaan hygiene sanitasi di kantin masih dirasa kurang penting dan belum sepenuhnya menjadi bagian dari pengelolaan pada perguruan tinggi. Padahal tanpa disadari akibat yang ditimbulkan apabila pengelolaan kantin tidak baik, dapat berdampak pada kesehatan lingkungan.

Mahasiswa di suatu perguruan tinggi memang tidak hanya membeli makanan yang tersedia di kantin perguruan tinggi saja, mereka dapat membeli makanan di sekitar perguruan tinggi yang bersangkutan yang pengelolaannya tentu diluar kewenangan manajemen perguruan tinggi tersebut. Tetapi kantin di suatu perguruan tinggi menjadi tanggung jawab dari perguruan tinggi tersebut, seperti diatur dalam keputusan menteri kesehatan RI nomor 715 tahun 2003. Menurut peraturan tersebut, yang disebut makanan jajanan adalah makanan dan minuman yang diolah oleh pengrajin makanan di tempat penjualan dan atau disajikan sebagai makanan siap santap untuk dijual bagi umum selain yang disajikan jasa boga, rumah makan/restoran, dan hotel. Pengelola kantin perguruan tinggi dalam hal ini disebut pengelola sentra adalah orang atau badan yang bertanggung jawab untuk mengelola tempat kelompok pedagang makanan jajanan. Jadi perguruan tinggi sebagai pengelola kantin mempunyai tanggung jawab atas apa yang dikelola di kantin perguruan tingginya, dan diatur oleh UU pemerintah.

Pentingnya hygiene sanitasi makanan jajanan dapat disadari dan dipahami oleh para penjaja makanan kantin, dilakukan dengan memberikan pengawasan dan penyuluhan oleh instansi (Pratiwi, 2012). Kegiatan penyuluhan hygiene sanitasi telah dilakukan di berbagai wilayah dan lingkungan fasilitas umum di Indonesia. Misalnya di lingkungan sekolah Dasar di Samarinda (Ningsih, 2014); warung makan di kota Sleman (Cahyaningsih et al., 2009); penjaja makanan di lingkungan sekolah menengah atas di Wonogori (Maharani, 2017); para pedagang es buah di pasar jajan Gorontalo (Tahaku, 2014); di lingkungan rumah sakit 
umum di Denpasar (Rapiasih et al., 2010); di lingkungan depot air minum isi ulang di kota Padang (Abdilanov et al., 2013) .

Upaya yang dilakukan oleh PTS X sebagai instansi atau lembaga yang mengelola para pelaku kantin penjaja makanan di lingkungan PTS tersebut adalah dengan memberikan pelatihan hygiene, yang diselenggarakan bersama tiga lembaga yakni PTS yang bersangkutan, BEDO (Business and Export Development Organization) dan ILO (International Labor Organization). Kegiatan pengabdian kepada penjaja makanan ini bertujuan untuk mengetahui sejauh mana penjaja makanan ini mengerti tentang hygiene sanitasi.Agar para penjual juga mengerti pentingnya hygiene sanitasi dari persepsi konsumen, maka disebarkan kuesioner terhadap para konsumen mengenai hygiene sanitasi. Penjelasan tentang hasil kuesioner ini diharapkan mampu memberi pengetahuan akan hygiene sanitasi yang selama ini terjadi di kantin tersebut. Pelatihan diberikan oleh tim dosen Program studi Manajemen PTS tersebut pada penjaja makanan di lingkungan internal PTS X. Dua hal yang sangat penting dan sebenarnya mudah untuk dilakukan oleh penjual makanan di kantin yaitu pengelolaan kebersihan pribadi (menyangkut penjual makanan dan minuman di kantin) serta kitchen management. Untuk pengelolaan kebersihan pribadi menjadi tanggung jawab dari penjual makanan dan minuman di kantin, sedangkan untuk kitchen management ada yang menjadi tanggung jawab penjual, seperti kebersihan dan pengelolaan peralatan masak dan makan, serta tanggung jawab pihak perguruan tinggi berkenaan dengan penyediaan sarana kantin dan pengelolaannya.

Pengelolaan kebersihan pribadi terdiri dari:

1. Pegawai yang melayani di kantin memakai pakaian yang bersih

2. Pegawai yang melayani di kantin tidak mempunyai luka baik ditangan

3. Pegawai yang melayani di kantin berkuku bersih

4. Pegawai yang melayani di kantin tidak sakit saat melayani
5. Pegawai yang melayani di kantin memakai celemek saat memasak

6. Pegawai yang melayani di kantin memasak dengan bersih

Sedangkan kitchen management terdiri dari:

1. Alat makan yang ada bersih

2. Alat memasak yang ada bersih

3. Area kantin selalu bersih

4. Area kantin selalu kering

5. Di area kantin tidak ditemukan lalat

6. Di area kantin tidak ditemukan tikus

7. Tersedia tempat sampah yang memadai

8. Meja dan kursi kantin memadai

9. Meja dan kursi kantin bersih

\section{METODE}

Penelitian ini berusaha melihat persepsi konsumen (dalam hal ini mahasiswa) terhadap hygiene sanitasi dari kantin, dilihat dari dimensi pengelolaan kebersihan pribadi dan juga kitchen management.

Kuesioner yang terkumpul sebanyak 450 orang, kuesioner disebarkan melalui online survey ke mahasiswa. Analisis deskriptif dilakukan dengan menghitung rata - rata jawaban responden dari setiap pernyataan yang dilampirkan. (Simamora, 2002) menyatakan batasan nilai dari setiap kategori dapat diketahui dengan menggunakan rumus:

$R S=\frac{(m-n)}{b}$

Keterangan:

RS = Rentan Skala

$\mathrm{M}=$ nilai tertinggi di dalam pengukuran (angka tertinggi dalam kuesioner)

$\mathrm{N}=$ nilai terendah di dalam pengukuran (angka terendah dalam kuesioner)

$\mathrm{B}=$ jumlah kelas (pilihan jawaban dalam kuesioner)

Diketahui pada kuesioner memiliki nilai tertinggi adalah lima dan nilai terendah adalah satu. Maka, nilai rentang skalanya adalah:

$R S=\frac{(5-1)}{5}=0.8$

Setelah diketahui besaran nilai rentang skala, maka dapat diketahui rentang skala dan kategori berdasarkan nilai rata - rata. 
Tabel 1

Kategori Nilai Rata - Rata Hitung pada Analisis Deskriptif Konsumen Kantin PTS X

\begin{tabular}{|c|c|}
\hline Rata - Rata Hitung & Kategori \\
\hline $1.00 \leq x \leq 1.80$ & Sangat Rendah \\
\hline $1.80 \leq x \leq 2.60$ & Rendah \\
\hline $2.60 \leq x \leq 3.40$ & Sedang \\
\hline $3.40 \leq x \leq 4.20$ & Tinggi \\
\hline $4.20 \leq x \leq 5.00$ & Sangat Tinggi \\
\hline
\end{tabular}

Sumber: Hasil Pengolahan Data

\section{HASIL DAN PEMBAHASAN}

\section{Isi Hasil dan Pembahasan}

Pada bulan Oktober 2017 dilakukan pelatihan hygiene oleh tim dosen program studi manajemen PTS $X$ dengan menggunakan materi hygiene yang dikembangkan oleh BEDO dan ILO. Pelatihan dihadiri oleh 17 dari 20 penjual yang ada di kantin PTS X. Sesudah sesi pelatihan diberikan diadakan sesi diskusi tentang apa yang harus diperhatikan oleh para pelaku usaha dan juga pemaparan hasil kuesioner yang diberikan kepada konsumen kantin tersebut. Dalam diskusi tersebut sebagian besar para penjual makanan dan minuman ini sudah sangat mengerti tentang pentingnya pengelolaan hygiene yang ada, tetapi mereka sangat menyayangkan masih kurangnya fasilitas yang ada, terutama dengan kondisi kantin saat ini yang merupakan kantin darurat, dikarenakan fasilitas yang dulu dalam masa pembangunan gedung baru. Kondisi kantin saat ini dinilai tidak memadai dikarenakan berada diluar lokasi area gedung salah satu fakultas, lokasinya di pelataran belakang gedung, dimana merupakan bangunan yang dibuat semi permanen. Apabila musim panas, maka kursi tempat konsumen duduk dan menyantap hidangan terasa sangat panas karena tanpa atap, tetapi disaat musim hujan maka lantai kantin menjadi becek dan memberi kesan kotor. Para penjual mengharapkan ada perbaikan untuk kondisi saat ini, karena dinilai pembangunan gedung baru akan memakan waktu cukup lama, sekitar kurang lebih dua tahun pembangunan. Dimana proses melayani penjualan makanan dan minuman harus tetap berjalan. Hasil survey terhadap mahasiswa tersebut dibagi menjadi dua dimensi, yaitu dimensi pengelolaan kebersihan pribadi dan kitchen management. Secara lengkap pembahasannya adalah sebagai berikut:

\section{Pengelolaan Kebersihan Pribadi}

Pengelolaan kebersihan pribadi membahas tentang bagaimana kebersihan pribadi yang dilakukan oleh para penyedia makanan dan minuman di kantin terbesar di PTS X, dimana dimensi ini berhubungan dengan enam pernyataan.

\section{Pegawai yang melayani di kantin memakai pakaian yang bersih}

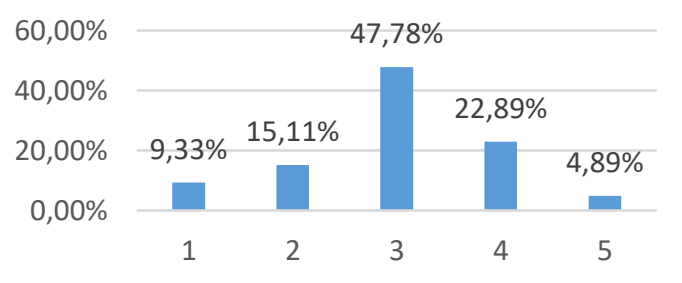

Sumber: data olahan

\section{Gambar 1}

Pegawai yang melayani di kantin memakai pakaian yang bersih

Menurut mahasiswa selama ini pegawai di kantin memakai pakaian yang bersih di $75,56 \%$, dengan rata-rata nilai sebesar 2,99 maka persepsi mahasiswa mengenai pegawai kantin memakai pakaian yang bersih berada pada kategori sedang. Apabila diperhatikan pakaian para pegawai di kantin relatif bersih dan layak. Mereka tidak berpakaian kotor walaupun mereka berhubungan dengan pengolahan makanan dari pagi sampai sore hari. 


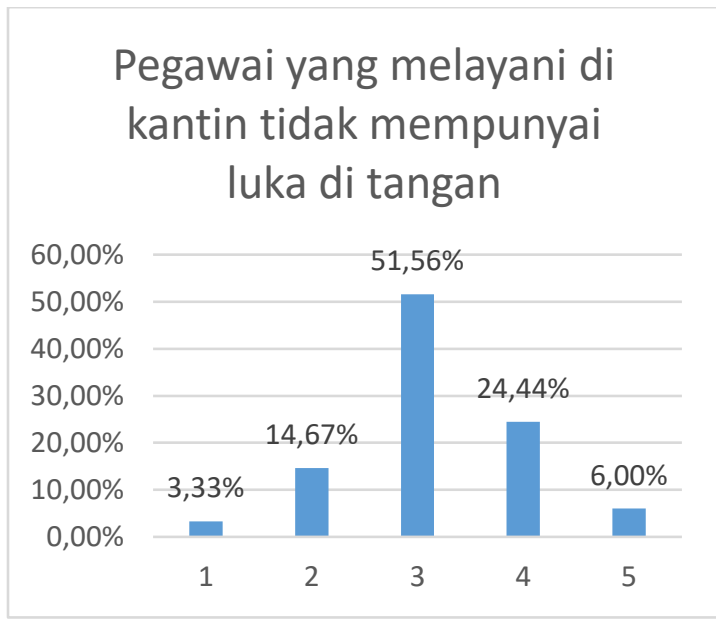

Sumber: data olahan

Gambar 2

Pegawai yang melayani di kantin tidak mempunyai luka di tangan

Dari data diatas terlihat bahwa $82 \%$ mahasiswa menjawab bahwa setuju pegawai yang melayani di kantin tidak memiliki luka di tangan. Rata-rata dari pernyataan itu sebesar 3,15 yang artinya masuk kategori sedang. Artinya konsumen melihat bahwa pegawai yang melayani di kantin tidak mempunyai luka di tangan, luka di tangan bagi penyedia jasa makanan bisa menjadi berbahaya karena luka terbuka bisa menjadi perantara penyebaran kuman dari satu orang ke orang lainnya.

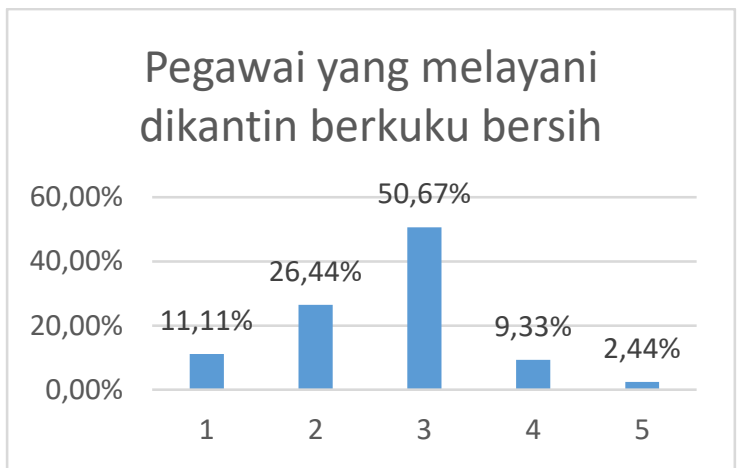

Sumber: data olahan

\section{Gambar 3}

Pegawai yang melayani di kantin berkuku bersih

Mahasiswa menilai bahwa pegawai yang melayani di kantin berkuku bersih dengan ratarata nilai sebesar 2,66 dimana masuk kategori sedang. Mahasiswa menilai bahwa kuku dari pegawai kantin cukup bersih, kebersihan kuku akan berpengaruh terhadap kesehatan dan kebersihan dari makanan yang disajikan.

Gambar 3.4 menunjukkan bahwa selama ini mereka menyadari bahwa pegawai yang melayani tidak sakit saat melayani konsumen. Rata-rata nilai yang didapat adalah 3,14 dimana masuk pada kategori sedang. Pegawai yang sakit seharusnya memang tidak melayani konsumen terutama dalam hal jasa makanan. Pegawai yang sakit akan dengan mudah menyebarkan virus atau bakteri melalui dirinya ke orang lain.

\section{Pegawai yang melayani dikantin tidak sakit saat melayani}

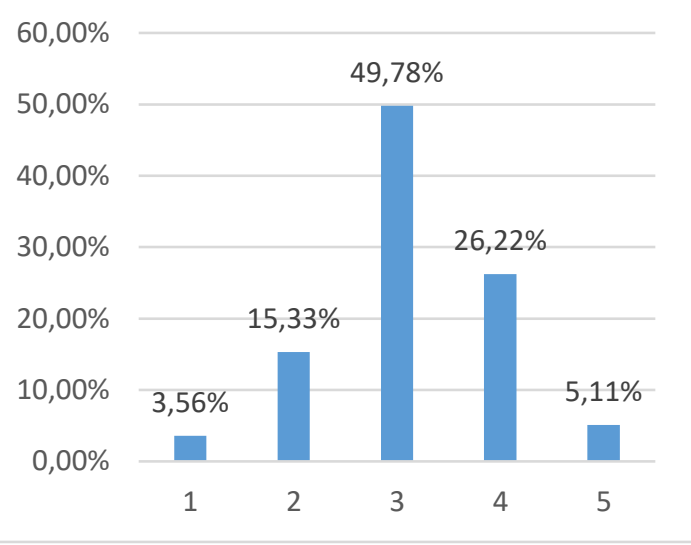

Sumber: data olahan

Gambar 4

Pegawai yang melayani di kantin tidak sakit melayani

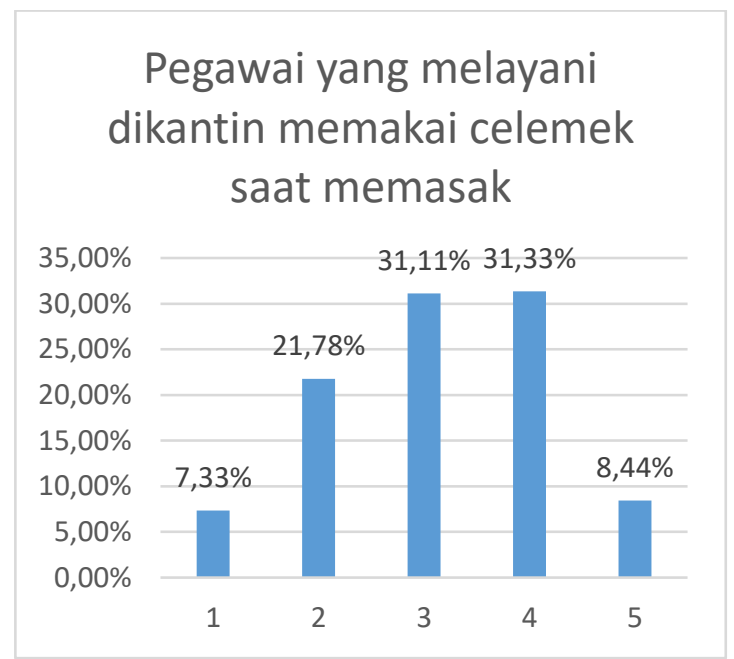

Sumber: data olahan

Gambar 5 


\section{Pegawai yang melayani di kantin memakai celemek saat memasak}

Mahasiswa menilai bahwa selama ini pegawai di kantin memakai celemek saat memasak sebesar 3.12, nilai ini masuk ke kategori sedang (Gambar 5) Mahasiswa setuju bahwa pegawai yang melayani memakai celemek saat memasak. Ini menunjukkan pengelolaan kebersihan pribadi yang baik, bahwa para pegawai harus menjaga kebersihan dirinya. Pada saat proses memasak kemungkinan pakaian dari pegawai terciprat minyak atau terkena kotoran makanan sangat wajar terjadi, untuk menjaga kebersihan pakaian yang dikenakannya pemakaian celemek sangat membantu pegawai.

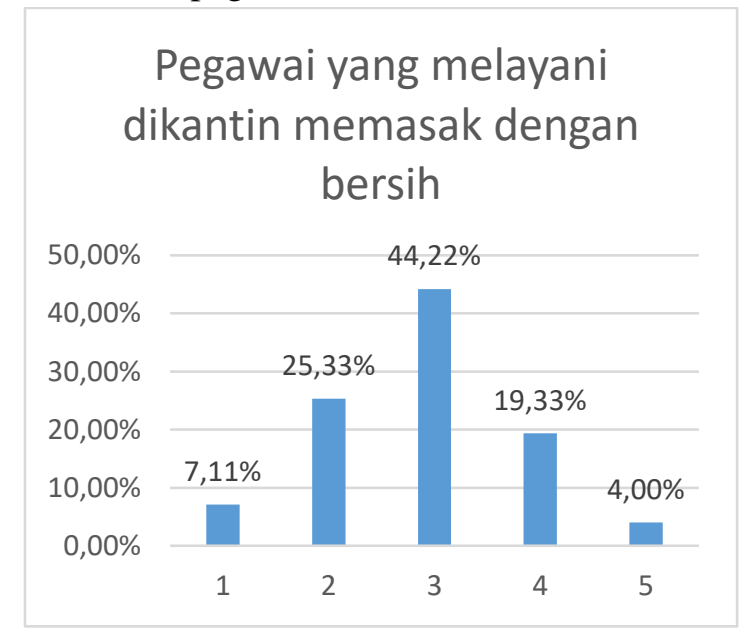

Sumber: data olahan

\section{Gambar 6}

Pegawai yang melayani di kantin memasak dengan bersih

Gambar 6 menunjukkan bahwa mahasiswa menilai pegawai yang melayani di kantin memasak dengan cukup bersih, dengan nilai rata-rata sebesar 2.88 yang termasuk kategori sedang. Saat ini proses memasak di beberapa penjual makanan maupun minuman sudah cukup bersih, ada beberapa yang meja penyajiannya kurang bersih pada saat jam padat melayani konsumen, karena sangat padatnya proses memasak dan melayani konsumen.

Dari keseluruhan pernyataan diatas, pengelolaan kebersihan pribadi memiliki nilai rata-rata sebesar 2.99, nilai ini masuk kategori sedang. Artinya bahwa mahasiswa menilai selama ini pengelolaan kebersihan pribadi masih berkisar cukup bersih saja. Perlunya terus pembinaan terhadap para penjual makanan dan minuman ini bahwa pengelolaan kebersihan pribadi menjadi poin yang penting yang harus diperhatikan pada saat menjual makanan ataupun minuman, karena kebersihan pribadi akan sangat berpengaruh terhadap kebersihan konsumen yang dilayaninya.

\section{Kitchen Management}

Dimensi kedua yang merupakan faktor penting adalah kitchen management. Kitchen management berhubungan dengan sembilan pernyataan yang menyangkut kebersihan peralatan makan dan minum yang disediakan serta kebersihan dari fasilitas yang ada. Pada dimensi ini ada peran dari penjual makanan dan minuman di kantin tetapi juga pihak perguruan tinggi swasta $X$ sebagai penyelenggara dan penanggung jawab kantin.

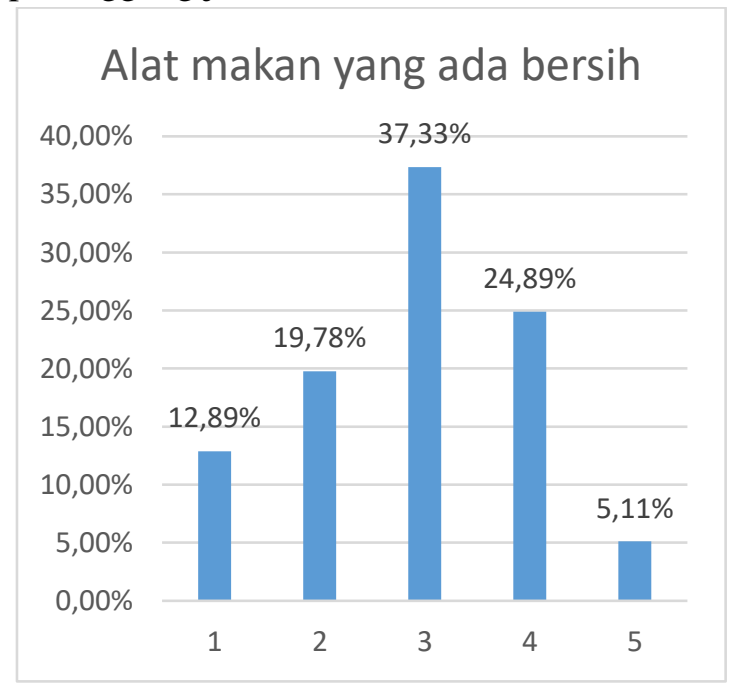

Sumber: data olahan

Gambar 7

Alat makan yang ada bersih

Gambar 7 menunjukkan bahwa masih ada sekitar 32\% mahasiswa yang berpikir bahwa peralatan makan yang disediakan tidak bersih. Rata-rata mahasiswa yang ada sebesar 2,9. Hal ini menunjukkan bahwa penilaian mahasiswa berkisar pada kategori sedang, mereka menilai kebersihan peralatan makan cukup bersih dan belum pada kategori bersih ataupun sangat bersih. Hal ini perlu ditingkatkan karena peralatan makan menjadi media penghantar 
makanan ke konsumen, efeknya akan sangat besar bagi kesehatan konsumen.

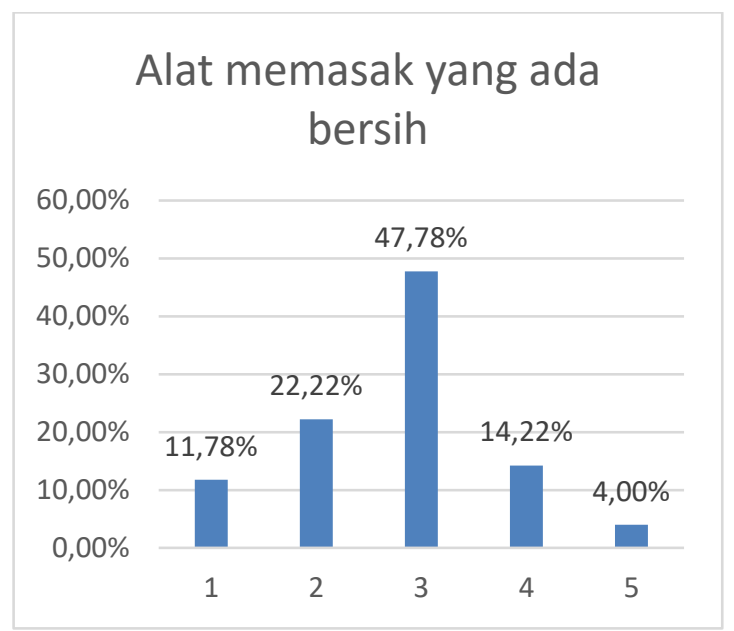

Sumber: data olahan

Gambar 8

Alat memasak yang ada bersih

Gambar 8 menunjukkan bahwa selama ini alat memasak yang dipakai para penjual lumayan bersih, dengan nilai rata-rata 2,76 yang masuk pada kategori sedang. Nilai kategori kebersihan rendah ada pada nilai 2,6, sehingga ini patut menjadi pusat perhatian. Kebersihan peralatan masak berhubungan dengan segala peralatan yang dipakai untuk memasak seperti wajan, bakaran sate, panci, blender serta kompor. Peningkatan pada pengelolaan kebersihan peralatan makan sangat diperlukan.

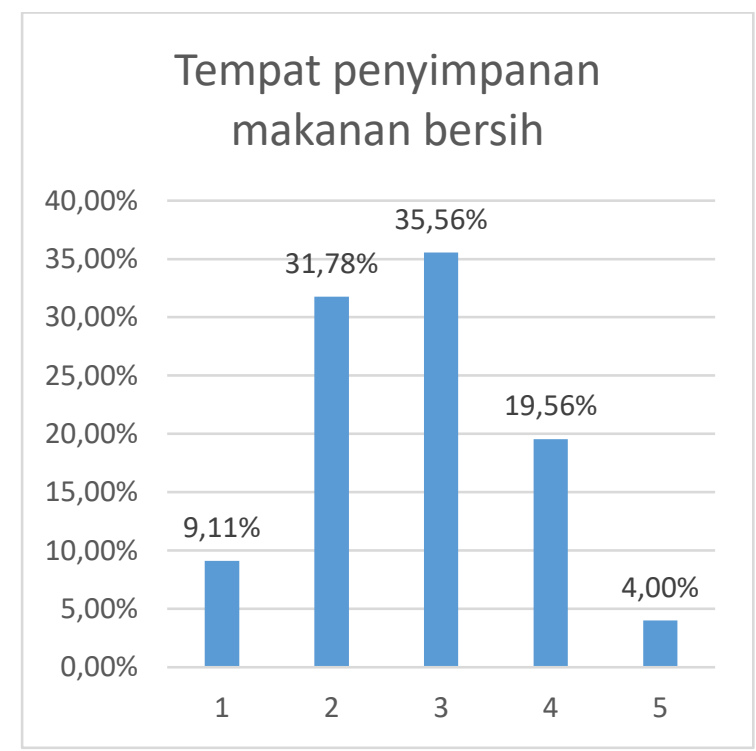

Sumber: data olahan

Gambar 9

Tempat penyimpanan makanan bersih
Gambar 9 menunjukkan bahwa tempat penyimpanan makanan yang ada di kantin selama ini cukup bersih dengan nilai rata-rata 2,78. Nilai rata-rata ini mendekati kategori yang rendah, jadi pembinaan dan pemberitahuan mengenai pentingnya kebersihan tempat penyimpanan menjadi sangat penting untuk saat ini.

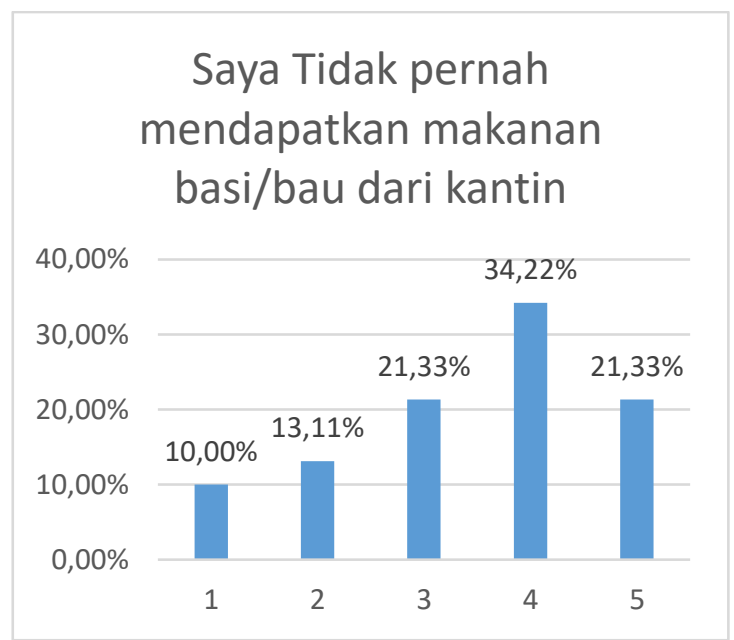

Sumber: data olahan

\section{Gambar 10}

\section{Saya tidak pernah mendapatkan makanan} basi/bau dari kantin

Gambar 10 menunjukkan bahwa mahasiswa merasa tidak pernah mendapatkan makanan basi/bau dari kantin dengan nilai rata-rata 3,44 yang berada pada kategori tinggi. Artinya tingkat kelayakan makanan ataupun minuman yang disajikan sudah baik. Hal ini perlu dipertahankan bahkan ditingkatkan, karena apabila melihat dari gambar 3.10 masih ada $23 \%$ mahasiswa yang mendapatkan makanan kurang baik. Akan sangat bagus apabila semua mahasiswa selalu mendapatkan makanan ataupun minuman yang layak konsumsi. 


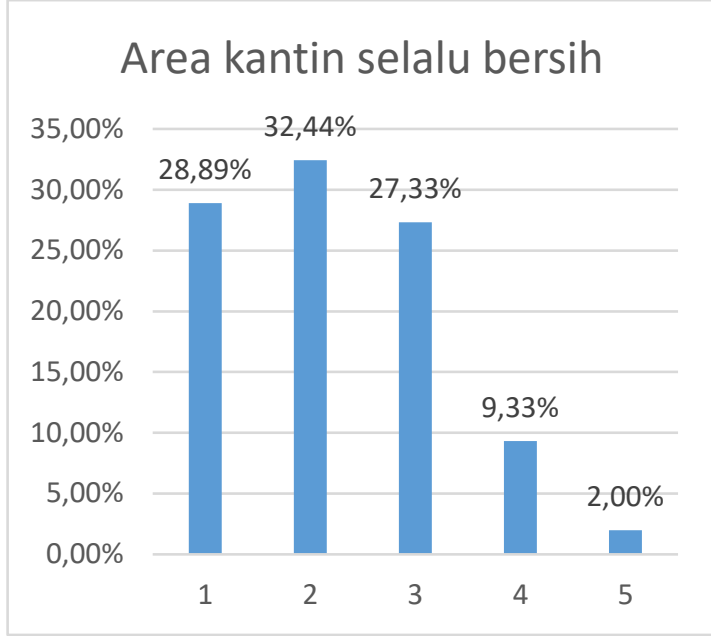

Sumber: data olahan

\section{Gambar 11}

\section{Area kantin selalu bersih}

Gambar 11 menunjukkan bahwa relatif sebagian besar mahasiswa menilai area kantin tidak selalu bersih. Nilai rata-rata sebesar 2,23 menunjukkan nilai pada kategori rendah. Kebersihan kantin berhubungan dengan fasilitas, ini menjadi tanggung jawab bersama antara para penjual dan penanggung jawab kantin. Berdasarkan diskusi dengan para penjual sebagian besar dari penjual merasa bahwa para penjual makanan dan minuman ini belum semuanya memiliki kesadaran untuk membersihkan meja atau area di luar tempatnya berjualan. Ada beberapa yang walaupun melihat meja kotor dan berantakan tidak mau membereskan karena merasa tidak ada konsumen yang memesan makanan atau minuman dari tempatnya. Hal ini mengemuka karena kejadian seperti ini seringkali terjadi.

Kesadaran untuk menjaga kebersihan kantin adalah tanggung jawab bersama belum sama di setiap penjual. Ada penjual yang merasa itu adalah tanggung jawab bersama, dan selama ini bersedia membereskan bahkan piring dari penjual yang lain, tetapi ada juga yang menilai kalau bukan konsumen saya maka saya tidak wajib membereskan. Peran dari perguruan tinggi sebagai pengelola dan penanggung jawab diperlukan pada kasus ini, karena perguruan tinggi-lah yang mereka anggap mampu memberikan arahan dan aturan yang harus diikuti oleh semua.

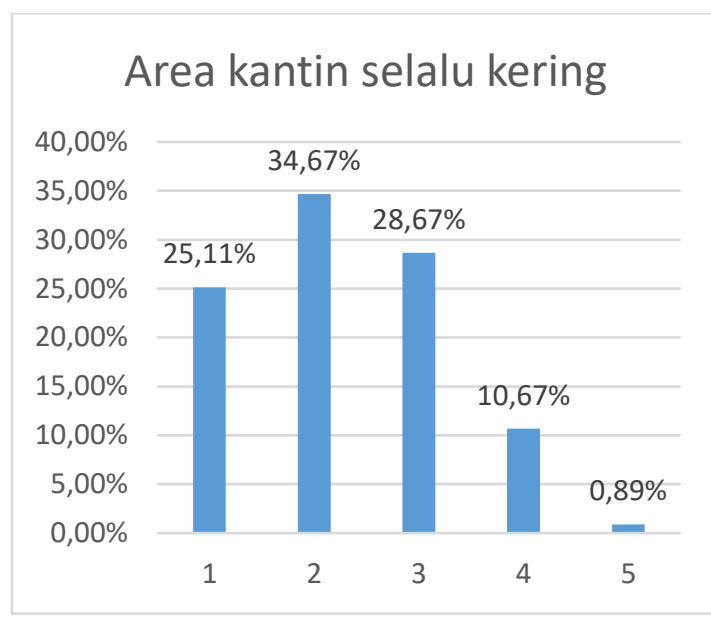

Sumber: data olahan

Gambar 12

\section{Area kantin selalu kering}

Gambar 12 menunjukkan bahwa area kantin tidak selalu kering, rata-rata pada pernyataan ini sebesar 2,28 yang berada pada kategori rendah, artinya area kantin relatif lebih sering basah. Hal ini bisa dilihat dari kondisi kantin yang semi permanen. Apabila hujan maka area makan mahasiswa terkena air hujan. Area memasak dan penyajian memang diberi atap, tetapi air hujan dari atap dan dari area yang tidak beratap membasahi semua wilayah kantin kecuali bagian dalam gedung semi basement gedung. Lantai yang basah dan becek menjadi kotor apabila semakin makin orang yang berlalu lalang. Untuk fasilitas ini pihak perguruan tinggi harus memikirkan cara seperti apa yang harus dilakukan, mengingat gedung baru untuk kantin baru akan selesai antara 1-2 tahun kedepan. 


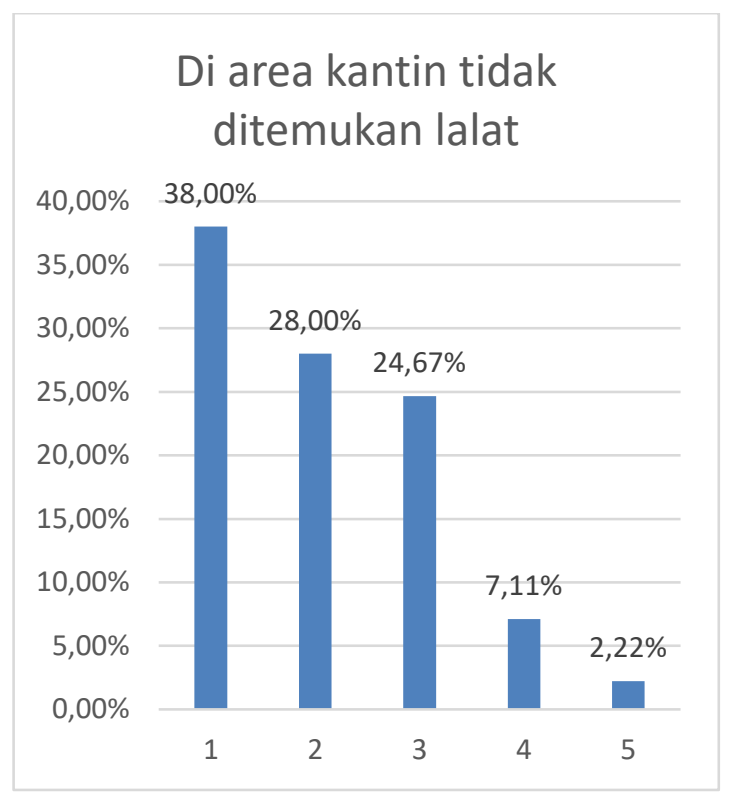

Sumber: data olahan

\section{Gambar 13}

Di area kantin tidak ditemukan lalat

Gambar 13 menunjukkan bahwa relatif banyak ditemui lalat di kantin, rata-rata mahasiswa memberikan penilaian sebesar 2,08, yang berada pada kategori rendah. Batas nilai ke kategori sangat rendah adalah 1,8 jadi ini sudah pada penilaian yang buruk. Adanya lalat di tempat makan berhubungan erat dengan kebersihan area tersebut. Untuk menghilangkan keberadaan lalat di area terbuka mungkin tidak mungkin tetapi dapat dilakukan hal-hal yang dapat meminimalisirnya seperti dngan pemasangan lem lalat, menutup tempat sampah, menutup tempat makanan, dan menjaga kebersihan area kantin sendiri. Banyak penyakit yang dapat disebarkan melalui lalat, jadi perbaikan kebersihan menjadi sangat penting.

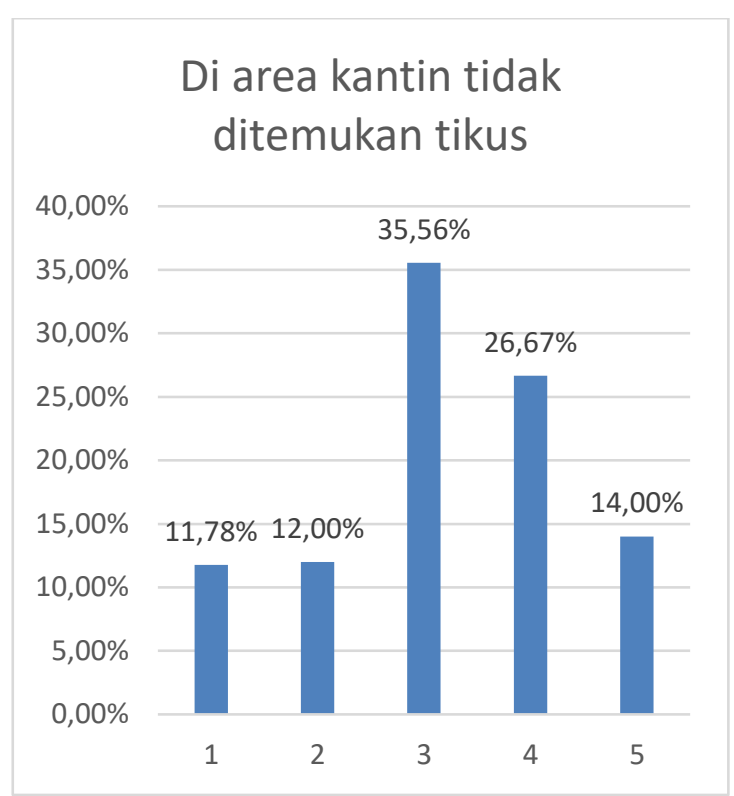

Sumber: data olahan

\section{Gambar 14}

\section{Di area kantin tidak ditemukan tikus}

Gambar 14 menunjukkan bahwa di area kantin saat ini jarang ditemukan tikus berkeliaran. Rata-rata penilaian mahasiswa sebesar 3,19 yang berada pada kategori sedang. Keberadaan tikus sama halnya dengan keberadaan lalat, sangat berhubungan dengan kebersihan area kantin. Dua faktor ini memang menjadi penentu apakah area kantin yang ada selama ini sudah bersih atau tidak. perguruan tinggi harus bekerja lebih keras untuk meningkatkan kebersihan di area kantinnya.

Gambar 15 menunjukkan bahwa penyediaan tempat sampah di area kantin masih berada pada kategori sedang dengan nilai rata-rata sebesar 2,95 . Untuk area kantin, apalagi dengan sebaran tempat mahasiswa untuk makan dan minum sangat tersebar diperlukan penyediaan tempat sampah yang relatif banyak dan juga bersih. Tempat sampah ini minimal harus diangkut sehari dua kali, karena disaat siang tempat sampah menjadi penuh dan menambah ketidakbersihan kantin serta sangat mengundang lalat yang datang. 


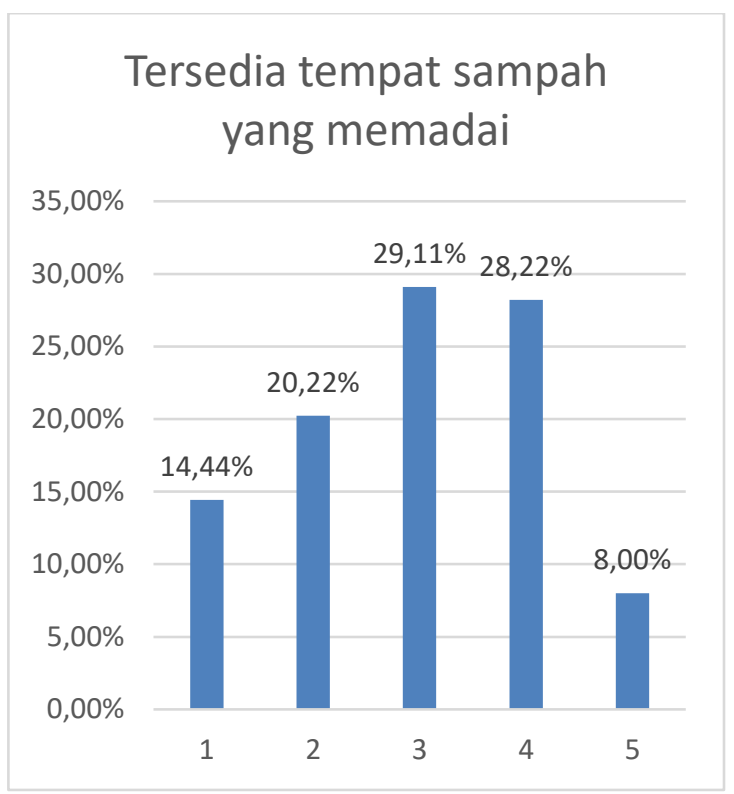

Sumber: data olahan

\section{Gambar 15}

\section{Tersedia tempat sampah yang memadai}

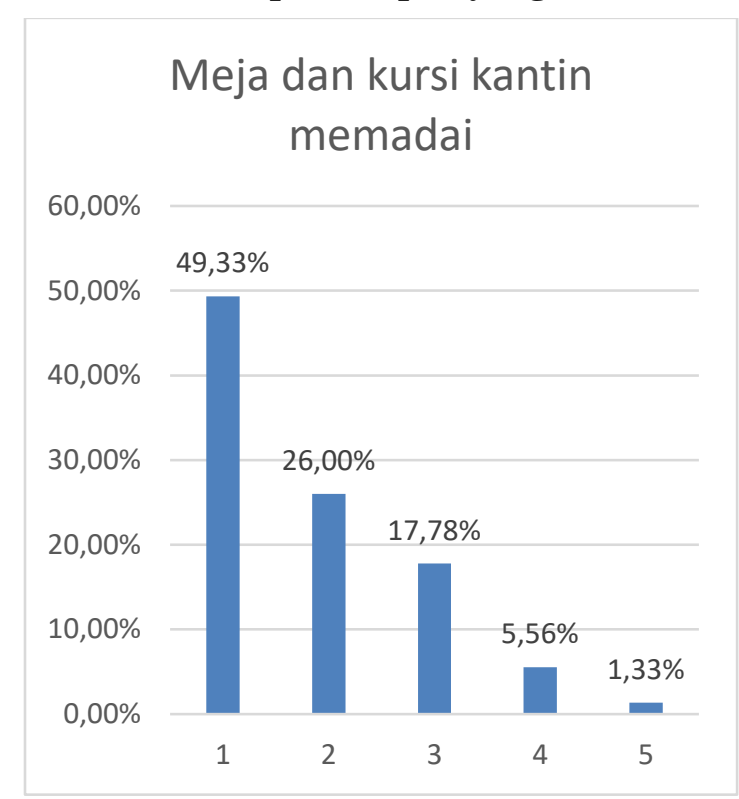

Sumber: data olahan

\section{Gambar 16}

\section{Meja dan kursi kantin memadai}

Untuk Gambar 16 ketersediaan meja dan kursi dinilai masih tidak memadai dengan nilai ratarata 1,84. Nilai ini mendekati nilai sangat rendah pada nilai 1,8 . Apabila dilihat memang kursi dan meja yang tersedia kurang jumlahnya, sehingga menjadi pemandangan umum pada saat kantin ramai mahasiswa akan makan sambil duduk di lantai maupun di tangga dekat lift. Lantai dan tangga bukanlah tempat yang baik untuk makan terutama di area yang padat seperti kantin.

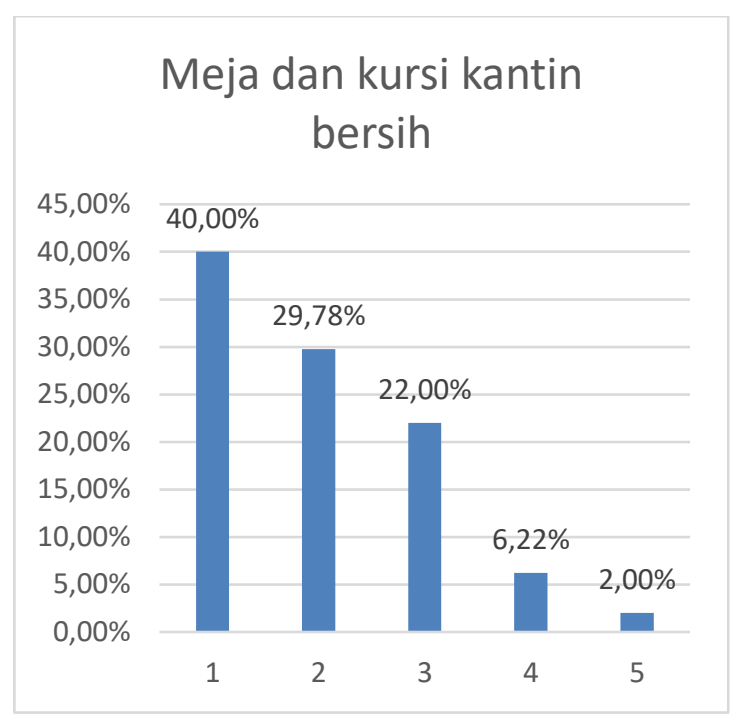

Sumber: data olahan

\section{Gambar 17}

\section{Meja dan kursi kantin bersih}

Pada gambar 17 terlihat bahwa meja dan kursi kantin selain tidak mencukupi jumlahnya juga masih dinilai kurang bersih. Nilai rata-rata yang ada pada nilai 2,00 yang berada pada kategori rendah. Ini berhubungan dengan kemauan dan ketersediaan dari pegawai kantin untuk membersihkan meja dan kursi yang kotor atau setelah selesai makan. Himbauan serta penambahan aturan dari pihak pengelola kantin atau perguruan tinggi sangat diperlukan. Kebersihan tidak hanya pada peralatan makan saja tetapi juga pada fasilitas yang ada, dan ini menjadi bukan hanya tanggung jawab pengelola kantin tetapi juga pihak perguruan tinggi.

Dari keseluruhan dimensi kitchen management nilai rata-ratanya adalah pada nilai 2,59 atau berada pada kategori rendah. Hal ini tentu mengkhawatirkan untuk sebuah kelayakan kantin suatu perguruan tinggi. Nilai rata-rata untuk pengelolaan kebersihan pribadi relatif lebih baik dari penilaian untuk kitchen management. Selain itu penilaian yang buruk pada kitchen management banyak berhubungan dengan fasilitas dan pengelolaan kebersihan kantin dibandingkan dengan kebersihan dari peralatan makan, sehingga peran perguruan tinggi sangat diperlukan dalam hal ini.

Apa yang dikeluhkan mahasiswa tentang kitchen management sejalan dengan apa yang dikemukakan oleh para penjual. 
Ketersediaan meja kursi yang kurang memadai, area kantin yang seharusnya kering tetapi Karena kantin saat ini merupakan kantin darurat sehingga menjadi basah di saat hujan. Kebersihan meja kursi masih dinilai rendah, sehingga diharapkan para penjual dapat bekerja sama dalam membersihkan meja dan kursi yang dipakai bersama.

Berdasarkan hasil persepsi konsumen kantin, tim dosen menindaklanjuti dengan memberikan pelatihan kepada penjaja kantin yakni tentang hygiene sanitasi dengan bersumber pada modul SCORE-ILO. Bentuk pelatihan adalah pemberian materi, diskusi dan role play, sehingga para penjaja kantin dapat langsung melakukan hal-hal terkait materi, seperti pemasangan tutup kepala saat mengolah makanan. Selain memberikan pelatihan, tim abdimas dosen juga memberikan starter kit yang berisi sarung tangan sekali pakai, tutup kepala dan masker bagi setiap penjaja makanan yang mengikuti pelatihan. Peserta sangat antusias dalam mengikuti pelatihan, dilihat dari banyaknya peserta yang hadir, mencatat, dan mengajukan pertanyaan. Hasil diskusi dan beberapa hal yang terkait dengan pengelolaan kantin dibantu penyampaiannya ke pihak pengelola dan pihak pengelola menyampaikan bahwa informasi yang didapat akan ditindaklanjuti.

\section{SIMPULAN}

Dari pembahasan diatas ditemukan temuan yang menarik, hasil diskusi pada program pelatihan menunjukkan pengetahuan akan pengelolaan kebersihan pribadi dari para penjual makanan dan minuman yang ada di kantin UNPAR saat ini sudah masuk kategori sedang atau cukup baik, masih bisa ditingkatkan menjadi lebih baik lagi karena para penjual sudah menyadari pentingnya arti kebersihan bagi mereka.

Tetapi dari analisa diatas ditemukan bahwa dimensi kitchen management yang berhubungan dengan fasilitas kantin dan bantuan dari pengelola kantin yaitu pihak perguruan tinggi masih harus diperbaiki karena berada pada kategori rendah. Apabila pihak perguruan tinggi tidak melakukan perubahan pengelolaan maka dikhawatirkan hal ini akan membawa dampak yang buruk bagi kesehatan dari konsumen kantin PTS X.

\section{UCAPAN TERIMAKASIH}

Ucapan terima kasih diberikan kepada Lembaga Penelitian dan Pengabdian Masyarakat (LPPM) Universitas Katolik Parahyangan, yang mendukung pendanaan kegiatan ini berlangsung.

\section{DAFTAR PUSTAKA}

Abdilanov, D., Hasan, W., \& Marsaulina, D. I. (2013). Pelaksanaan Pengelenggaraan Hygiene Sanitasi dan Pemeriksaan Kualitas Air Minum pada Depot Air Minum Isi Ulang di Kota Padang tahun 2012. Lingkungan Dan Keselamatan Kerja, 2(3), 14409.

Cahyaningsih, C. T., Kushadiwijaya, H., \& Tholib, A. (2009). Hubungan higiene sanitasi dan perilaku penjamah makanan dengan kualitas bakteriologis peralatan makan di warung makan. Berita Kedokteran Masyarakat, 25(4), 180.

Maharani, E. (2017). Hubungan Hygiene Sanitasi Penjamah Makanan dengan Angka Kuman Makanan Jajanan Sekitar SMA Negeri 3 Wonogini The Hygiene Sanitation Relationship of Food Handlers With The Number Germ of Food Snack In About SMA 3 Wonogiri. IKESMA, 12(2).

Persyaratan Hygiene Sanitasi Jasaboga Menteri Kesehatan Republik Indonesia, (2003).

Ningsih, R. (2014). Penyuluhan Hygiene Sanitasi Makanan dan Minuman, Serta Kualitas Makanan yang Dijajakan Pedagang di Lingkungan SDN Kota Samarinda. KEMAS, 10(1), 64-72.

Prabu. (2008). Higiene dan Sanitasi Makanan | Kesehatan Lingkungan. 2008.

Pratiwi, D. (2012). Hygiene sanitasi pedagang kue dan keberadaan Escherichia coli pada makanan jajanan kue cucur di wilayah pasar tradisional Desa Kaliyoso Kecamatan 
Bongomeme Kabupaten Gorontalo Tahun 2012. Public Health Journal, 1(1), 37212.

Rapiasih, N. W., Prawiningdyah, Y., \& Lestari, L. . (2010). Pelatihan hygiene sanitasi dan poster berpengaruh terhadap pengetahuan, perilaku penjamah makanan, dan kelaiakan hygiene sanitasi di instalasi gizi. Jurnal Gizi Klinik Indonesia, 7(2), 64-73.

Simamora, B. (2002). Panduan riset perilaku konsumen. PT. Gramedia Pustaka,Jakarta.

Sumarni, N., Rosidin, U., \& Sumarna, U. (2020). PENYULUHAN KESEHATAN TENTANG JAJANAN SEHAT DI SEKOLAH DASAR NEGERI JATI III TAROGONG KALER GARUT. Kumawula: Jurnal Pengabdian Kepada Masyarakat, 3(2), 289297.

https://doi.org/https://doi.org/10.24198/kumaw ula.v3i2.28026

Tahaku, N. (2014). Hygiene Sanitasi Pengolahan dan Uji Keberadaan Bakteri Escherichia Coli pada Es Buah yang Dijajakan Dipasar Jajan Kota Gorontalo. Public Health Journal, 1(1), 37267. 